\title{
The National Guard:
}

\section{Another Argument for DC Statehood?}

\author{
By Catherine Kaufman
}

https://doi.org/10.4079/pp.v28i0.10

This previously appeared on Brief Policy Perspectives in February 2021 and was not subject to the same review process as our peer-reviewed journal articles.

In the wake of the January 6 insurrection and the inauguration of a new president of the United States (US), the National Guard and Washington, DC have both captured the national spotlight. The lack of police response to the attack on the Capitol has largely been considered a failure, and DC Mayor Muriel Bowser has blamed her inability as Mayor to call in the National Guard when needed as a large part of the reason why more was not done, reiterating her calls for DC statehood (Woodward-Burns 2021). With a new slight Senate majority, Democrats have reintroduced a bill that would make DC the 51st U.S. state, fueled at least in part by the arguments raised about the National Guard chain of command throughout 2020 and into 2021 (Shabad 2021).

\section{HEROES OR OPPRESSORS?}

In another Policy Perspectives blog post from the summer of 2020, Nathalie Grogan describes the perception of Guardsmen as "whiplash" going back and forth from "heroes to oppressors" over the years (Grogan 2020). This narrative has seemed to play out in DC over the past few months and weeks alone: over the summer, Trump deployed more than 4,000 National Guard troops to DC to combat racial justice protests, while he sent only 1,100 troops on January 6 by late evening, well after the rioting had stopped (Beck 2021). DC residents met both choices with outrage, with the Mayor initially saying that active-duty troops were not welcome in DC, and then saying there were not enough Guardsmen to protect the city (Sisk 2020; Woodward-Burns 2021).

The day after the insurrection, after the National Guard had been called in, Bowser and the Capitol police were skewered in the media for allegedly making the Guardsmen sleep in a parking garage, with little to no regard for comforts or safety - and as of January 25, almost 200 Guardsmen serving in DC have contracted the coronavirus (Seligman 2021; Harkins 2021). Immediately after news reports came out, Democrats in the federal government issued apologies and quickly moved the Guardsmen to different accommodations, but not before lawmakers from both sides of the aisle heavily criticized their treatment even after they 
were celebrated the previous day for their service protecting the city during inauguration (Zitser 2021; Barr 2021).

But the local response to each of these DC National Guard (DCNG) deployments has little to do with general perceptions of the Guard itself - it has to do with who is deploying them. In a period of racial justice protests against police brutality, the federal government called in troops unwanted by the residents or by the Mayor. And when the troops were wanted by the residents and the Mayor during the transition of power, they were difficult to come by.

To understand how a more logical chain of command might be established for the DCNG, it is first important to know how it is currently structured.

\section{HOW IS THE DC NATIONAL GUARD STRUCTURED?}

The chain of command regarding the National Guard is different in DC than it is for the states, and it is problematic for the residents of the District. Each state has their own National Guard organizations, and there are four additional ones-Guam, Puerto Rico, the US Virgin Islands, and DC - three of which are controlled locally unless they are federalized. Only the DCNG cannot, due to a DC Code enacted by the US Congress before the DC local government was created that establishes the president as the DCNG commander (Goitein 2021; DCC § 49409). Importantly, while other National Guard organizations are locally funded, the DCNG is funded at the federal level.

Elizabeth Goitein and Joseph Nunn of the Brennan Center for Justice explain this strange hierarchy and the problems that can arise because of it (Goitein 2021). First, the chain of command creates a "loophole" in the Posse Comitatus Act (PCA), which essentially places a penalty on anyone who uses "any part of the Army or the Air Force as a posse comitatus," or a group mobilized by the government to suppress lawlessness, unless expressly authorized by Congress (USC $\S 1385$ ). In DC, the DCNG is able to operate in a non-federal way, even though it is federally controlled and funded (Department of Justice 1989). Goitein and Nunn described what happened in June 2020 as the "equivalent of a large-scale federalization of the Guard to perform a domestic policing function - exactly what the PCA was designed to prevent" (Goitein 2021).

Second, unlike state governors, the DC mayor is unable to call upon the National Guard to help with a public health crisis (like a pandemic), and natural disaster, or even to maintain public order without the okay from the federal government. The January 6 insurrection and apprehension around the transition of power are a stark example of why this command can be problematic, for almost exactly the opposite reasons as the first.

\section{STATEHOOD: THE BEST WAY TO FIX THE PROBLEM?}

While the Mayor and many others have called for statehood to fix the troubling problems caused by the DCNG chain of command, members of Congress have recently reintroduced legislation that would give Mayor Bowser the same control of her National Guard that state 
governors currently enjoy (Flynn 2021). This measure seems like a more realistic, quicker patch (or, as The Washington Post calls it, a steppingstone) to cover a much larger problem of DC's status as a district, rather than a state (Flynn 2021).

DC residents, approximately 43 percent of whom are Black, have been fighting for statehood long before this year (DC Health Matters 2021). They are fighting for representation in the federal government and for the ability to have the same decision-making ability as the rest of the country's citizens. And in recent years, according to the campaign director of 51 for 51 , it has been more widely painted as an issue of justice, not just as a political move-especially after the protests against police brutality after the murder of George Floyd this summer highlighted both racial injustice across the country and a lack of representation for everyone here in DC (CaplanBricker).

The movement has been gaining steam for years. But the spotlight on the National Guard has certainly helped to advance the statehood cause, with activists taking advantage of the publicity to push for change (Srikanth 2021). Of course, some are a bit dismayed about the reason for the attention-Jamal Holtz, a co-lead organizer for 51 for 51, stated that the real motivator behind statehood should be disenfranchisement, not a security breach (Caplan-Bricker 2021).

On the whole, however, recent changes and renewed debates have increased hope for change. Some even speculate that, with a publicly discussed justification of National Guard command combined with a racial reckoning and a Congress newly (and barely) controlled by Democrats, DC statehood might be better positioned now than perhaps it ever has been (Ayres 2021). 


\section{REFERENCES}

Ayres, Ian. 2021. “Op-Ed: Why the Capitol riot could speed up D.C.'s path to statehood.” The Los Angeles Times, January 25, 2021. https://www.latimes.com/opinion/story/2021-0125/d-c-statehood-capitol-riot

Barr, Luke. 2021. "Lawmakers outraged at images of National Guard sent from Capitol to parking garages." ABC News, January 22, 2021. https://abcnews.go.com/Politics/lawmakers-outraged-images-national-guard-capitolparking-garages/story? $\mathrm{id}=75426790$

Beck, Madelyn. 2021. "A BLM Protest Brought Thousands Of National Guardsmen To D.C. In June. Where Were They Wednesday?” Boise State Public Radio, January 8, 2021. https://www.boisestatepublicradio.org/post/blm-protest-brought-thousands-nationalguardsmen-dc-june-where-were-they-wednesday\#stream/0

Caplan-Bricker, Nora. 2021. "Is D.C. Finally on the Brink of Statehood?" The Washington Post Magazine, January 27, 2021. https:/www.washingtonpost.com/magazine/2021/01/27/dcstatehood-activists/?arc404=true

District of Columbia Code (DCC) § 49-409. 1889. President to be Commander-in-Chief. https://code.dccouncil.us/dc/council/code/sections/49-409.html

DC Health Matters. 2021. “2021 Demographics.” DC Health Matters, January 2021. https://www.dchealthmatters.org/demographicdata

Department of Justice. 1989. "Use of the National Guard to Support Drug Interdiction Efforts in the District of Columbia." April 4, 1989. https://www.justice.gov/file/24191/download

Flynn, Megan. 2021. "Local members of Congress propose giving D.C. control of its National Guard troops." The Washington Post, January 28, 2021. https://www.washingtonpost.com/local/dc-politics/bowser-national-guard/2021/01/28/89734636-61ba-11eb-9430-e7c77b5b0297 story.html

Goitein, Elizabeth and Joseph Nunn. 2021. "Why DC's Mayor Should Have Authority Over the DC National Guard.” Brennan Center, January 8, 2021. https://www.brennancenter.org/our-work/analysis-opinion/why-dcs-mayor-should-haveauthority-over-dc-national-guard

Grogan, Nathalie. 2020. "The Pandemic and the Protests: Necessity and Perception of the National Guard.” Brief Policy Perspectives, July 13, 2020. https://policyperspectives.org/2020/07/13/the-pandemic-and-the-protests-necessity-and-perception-ofthe-national-guard/

Harkins, Gina. 2021. "DC Guard Chief 'Deeply Troubled' After Nearly 200 Troops Test Positive for COVID-19.” Military.com, January 25, 2021. https://www.military.com/daily- 
news/2021/01/25/dc-guard-chief-deeply-troubled-after-nearly-200-troops-test-positivecovid-19.html

Seligman, Lara, Natasha Bertrand, and Andrew Desiderio. 2021. “'We feel incredibly betrayed': Thousands of Guardsmen forced to vacate Capitol.” Politico, January 21, 2021. https://www.politico.com/news/2021/01/21/national-guard-troops-vacate-capitol-461220

Shabad, Rebecca. 2021. "Democrats introduce bill to make Washington, D.C., the 51st state." NBC News, January 27, 2021. https://www.nbcnews.com/politics/congress/democratsintroduce-bill-make-washington-dc-51st-state-n1255841

Sisk, Richard. 2020. "Active-Duty Troops Not Welcome in DC, Mayor Says." Military.com, June 2, 2020. https://www.military.com/daily-news/2020/06/02/active-duty-troops-notwelcome-dc-mayor-says.html

Srikanth, Anagha. 2021. "DC statehood advocates sound off as National Guard is activated." The Hill, January 6, 2021. https://thehill.com/changing-america/respect/equality/532991-dcstatehood-advocates-sound-off-as-national-guard-is

US Code (USC) § 1385. 1956. Use of Army and Air Force as posse. comitatus.https://www.law.cornell.edu/uscode/text/18/1385

Woodward-Burns, Robinson. 2021. "The best way to secure the Capitol is to make D.C. a state." The Washington Post, January 13, 2021. https://www.washingtonpost.com/outlook/2021/01/13/dc-national-guard-bowser-capitolriot-statehood/

Zitser, Joshua. 2021. "Biden apologizes to National Guard chief after 5,000 soldiers had to reportedly sleep in a DC parking garage with only one bathroom." Business Insider, January 23, 2021. https://www.businessinsider.com/national-guard-biden-apologisestroops-that-slept-in-parking-lot-2021-1 